\title{
㓔痕疮㾑基础、临床研究以及临床转化的研究 进展和现状分析
}

\author{
张明子, 张文超, 龙飞, 斯楼斌, 俞楠泽, 曾昂, 刘志飞, 宋可新, 王友涁, 龙笑, \\ 王晓军*
}

中国医学科学院 \&北京协和医学院, 北京协和医院整形美容外科, 北京 100730

*联系人, E-mail: pumchwxj@163.com

收稿日期: 2021-04-17; 接受日期: 2021-06-19; 网络版发表日期: 2021-08-16

国家自然科学基金青年项目(批准号: 81801926)和国家自然科学基金面上项目(批准号: 81971846)资助

摘要痏痕疮㾂是一种皮肤良性肿瘤, 由于其发病机制尚不明确, 一直是整形外科领域的治疗难题. 近些年来关 于疫痕疮㾂的基础和临床研究较为广泛和丰富, 也有成功的临床转化案例. 本文对过去近20余年的相关研究进行 归纳、总结和分析, 探讨痒痕疮㾑基础、临床研究以及临床转化成果的相关进展, 并展望瘏痕疮㽽未来的研究 方向.

关键词瘏痕疮㽽, 基础研究, 临床研究, 临床转化, 进展

㓔痕疮痁是一种皮肤良性肿瘤，在黄种人群的发 病率可高达 $4 \% \sim 16 \%{ }^{[1]}$ ，但是具有恶性肿瘤向周围正 常组织浸润性生长的特点 ${ }^{[2]}$. 痏痕疮㾂可以生长在体 表的任何部位，常见的部位包括耳部、下领、前胸 部、后背部、会阴部以及足底, 并且可伴有难以忍受 的瘙痒和/或刺痛感，因此对患者的生活质量和精神状 态造成了严重的影响 ${ }^{[3]}$. 痏痕疮㾑组织内部伴有慢性 炎症，易发生感染、破溃，经久不愈的溃疡可发生癌 变导致㓔痕癌, 预后差, 具有较高的死亡率 ${ }^{[4,5]}$. 目前㓔 痕疮㾂的发病机制尚不明确, 其基础研究和临床研究 也较为丰富，有统计显示，2000 2020年的20年间，国 际上关于痒痕疮㾂的相关文献共计约 2693 篇, 其中基 础方面的研究多集中在细胞水平、信号通路和发病机
制, 临床方面的研究多集中在相关性分析以及新的治 疗方法的探索方面 ${ }^{[6]}$, 这其中也有较为成功的临床转 化案例, 本文就以上内容进行归纳、总结、分析和 展望.

\section{1 㓔痕疮㾑基础研究的进展及局限性探讨}

瘏痕疮㾂的发病机制不明，目前对于㓔痕疮㽽的 形成有多种假说, 例如免疫学假说、张力假说、内分 泌假说等. 在较早期的研究中, 学者们发现痈痕疮㾂 组织中 $\operatorname{IgG}$ 的表达水平显著升高, 因此一度认为这是 一种自身免疫性疾病 ${ }^{[7]}$. 此外, 早期的研究也发现, 相 比正常组织, 瘢痕疮㾑中 $T$ 细胞、 $B$ 细胞、巨噬细胞的

引用格式: 张明子, 张文超, 龙飞, 等. 痏痕疮㾂基础、临床研究以及临床转化的研究进展和现状分析. 中国科学: 生命科学, 2021, 51: 1140-1147 Zhang M Z, Zhang W C, Long F, et al. Progress and analysis of basic and clinical research and clinical transformation of keloids (in Chinese). Sci Sin Vitae, 2021, 51: 1140-1147, doi: 10.1360/SSV-2021-0104 
数量以及外周循环中免疫复合物含量显著升高, 更推 测痒痕疮㾂的增殖可能是由于免疫性刺激导致的 ${ }^{[8,9]}$. 基于以上研究, 临床瘏痕疮㾂免疫疗法的常用药物包 括他克莫司、咪喹莫特和干扰素(interferons, IFNs), 但以上药物目前并非痏痕疮㾂治疗的临床一线用药, 原因可能在于其所带来的全身不良反应. 免疫学假说 早在 40 年前就已经被提出, 但由于研究水平的限制, 近几十年痒痕疮㾂免疫学方面的研究主要停留在炎症 水平方面. 随着研究的深入, 近些年来, 对于免疫细胞 的研究成为瘏痕疮㾑免疫学的热点 ${ }^{[10 \sim 12]}$.

临床医师也会通过机械张力来解释㓔痕疮㾑易发 于皮肤张力较高的部位, 如前胸、背部等. 目前相关的 机制研究集中于机械敏感性离子通道、G蛋白偶联受 体、整合素等方面，它们将机械张力信号转化为分子 化学信号, 在TGF- $\beta$ /Smad通路、TNF- $\alpha$ 通路等发挥作 用 ${ }^{[13,14]}$. 近期, 宋海峰等人 ${ }^{[15]}$ 的体外实验结果表明, 张 力可能通过促进纤维化标志基因的表达, 增加瘷痕疮 㽽成纤维细胞的增殖和迁移能力, 促进瘢痕疮㾑的纤 维化进程. 但由于疫痕疮㾂的动物模型难以稳定建立, 所以该学说更细致和具有说服力的实验研究较欠缺. 在临床方面, 减少疟痕疮㾂切除后的皮肤缝合张力是

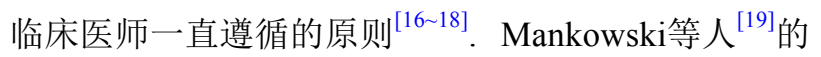
荟萃分析也得出结论, 认为张力是导致痒痕疮㾂术后 复发的重要原因.

瘏痕疮㽽内分泌方面的研究相对其他领域的研究 来说较少, 最早的研究起始于 40 年前. 内分泌方面的研 究方向主要集中于性激素(包括雄激素、雌激素)对㓔 痕疮㾑发生发展的作用 ${ }^{[20-24]}$. 研究表明, 性激素对瘏 痕疮㾑的生长具有一定的促进作用, 但是后续并无进 一步的研究, 临床也尚无性激素方面的治疗药物和治 疗方案, 整体的临床转化效果较弱, 并非主流研究 方向.

与内分泌假说类似，遗传方面的假说基本停留于 流行病学的调查研究和基因水平的基础研究. 早期的 研究重点在于得出遗传方式的结论, 早期学者们认为 瘷痕疮㾑是常染色体隐性遗传 ${ }^{[25]}$, 现如今随着研究群 体的深入和样本量的扩大, 研究结果更倾向于常染色 体显性遗传 ${ }^{[26,27]}$. 随着研究的深入, 学者们认为, 㓔痕 疮㾑的发病可能并不能通过简单的遗传模式进行解 释, 因此现在的研究热点在基因位点的突变、DNA甲 基化、非编码RNA等方面 ${ }^{[28-32]}$. 基因学方面的临床转
化案例较为少见.

除了单方面的假说外, 也有学者提出了综合发病 的假说. 2015年, Hochman等人 ${ }^{[33]}$ 提出了一种新的假 说来解释痈痕疮㾂的发病机制, 即心理神经免疫-内分 泌假说. 该假说认为, 皮肤与其附件以及其他的脏器、 中枢神经系统等存在相互作用, 当发生外伤时, 皮肤与 上述相关结构会引起连锁反应, 从而触发愈合机制, 但 当该连锁反应出现异常, 则会产生不良的愈合结果. 该 假说首次以多角度来解释疟痕疮㾑的发病机制, 但并 无进一步的研究证实和临床治疗方案的改进.

近些年来, 干细胞已经成为各种疾病的研究热点, 在痈痕疮㽽的基础研究中也不例外. 2008年，Moon等 人 $^{[34]}$ 首次分离出了痒痕疮㽽来源的间充质干细胞. 该 研究为痈痕疮痁的干细胞研究打开了新的大门, 但对 于瘷痕疮㽽来源的间充质干细胞研究在 2008 年之后也 基本停滞不前, 并无显著的突破性进展. 国内也仅 Deng等人 ${ }^{[35]}$ 的研究初步探讨了该类型干细胞相关基 因的表达水平. 除上述干细胞外, Zhang等人 ${ }^{[36]}$ 也从痏 痕疮㽽组织中分离出了肿瘤样干细胞, 并提出炎性反 应IL-17/IL-6轴可能在㓔痕疮㽽干细胞的转归中发挥 重要作用.

在宏观方面, Liu等人 ${ }^{[37]}$ 打开了㓔痕疮痁血流学方 面研究的大门. 他们的研究发现, 痈痕疮㾑边缘 $3 \mathrm{~mm}$ 内的皮肤组织已经出现血流水平方面的变化, 在组织 学方面, 瘷痕疮㾑邻近组织的皮肤VEGF的表达水平 也出现显著性改变, 这就意味着疫痕疮㾑周边的邻近 皮肤可能已经出现了“㓔痕疮㾂化”现象. Liu等人的研 究中所使用的激光散斑对比成像系统目前也开始应用 于临床, 以判断痒痕疮㾑是否处于相对活跃的阶段.

综上所述, 由于痗痕疮㾑的发病机制尚不明确, 因 此痈痕疮㾂基础方面的研究仍以解释痏痕疮㾂的发病 机制为出发点, 并为临床治疗提供相应的理论基础、 数据支持和治疗方向，但上述基础研究的临床转化率 尚较低.

\section{2 瘏痕疮㾂临床研究的进展及局限性探讨}

瘏痕疮㾑目前最主要的治疗方式是手术切除, 但 单纯手术切除后存在较高的复发率, 因此手术切除后 往往需要联合其他辅助的治疗方式, 其主要目的就是 减小手术切口再发㓔痕疮㽽的概率. 
在手术切除方面, 除了切除缝合外, 对于面积较大 的痒痕疮㾂, 还会应用皮肤移植、皮瓣转移、瘢痕疮 㾂部分切除配合表皮回植、扩张皮瓣等技术 ${ }^{[38]}$. 㓔痕 疮㽽手术方面的创新大多集中于过去的 $5 \sim 10$ 年, 主要 针对的是较大面积痏痕疮㾂的手术切除方式. 手术切 除配合放射治疗是较为常规的痏痕疮㾑治疗方式, 但 是较大面积的㓔痕疮㾂如果通过植皮的方式 I 期关闭 创面, 在术后行放射治疗的同时, 很可能影响皮片的存 活. Li等人 ${ }^{[39]}$ 在 2014 年报道了瘷痕疙㾑预切开预放疗 技术, 即先行瘷痕疮痁边缘切开, 同期行第一次放疗, 其后切除㓔痕疮痁并植皮治疗, 术后皮片存活后再行 二次放疗, 这样既可以保证皮片的存活, 也可以满足 放疗的总体剂量, 减少㓔痕疮㾂的复发. 显微外科技 术在瘏痕疮㾂手术中的应用也具有创新性, Zeng等 人 $^{[40]}$ 于 2017 年应用了 $\mathrm{Li}$ 等人的预切开预放疗技术, 并 报道了旋髂浅动脉穿支皮瓣游离移植的疫痕疮㾂治疗 方式, 皮瓣的质地、色泽均优于皮片, 术后效果良好.

放疗是痏痕疮㾑最主要的辅助治疗手段, 而手术 结合放疗也是目前㓔痕疮㾂治疗的首选方式 ${ }^{[41]}$. 目前 放疗对于痒痕疮㾂的作用原理仍不明确, 有研究指出, 放疗可能是通过调节体液、细胞分泌等减少疫痕疮㾂 的复发 ${ }^{[41]}$. 放疗对㓔痕疮㾂的作用根据剂量和时间的 不同, 可以引起细胞周期的停滞、调亡、衰老等表

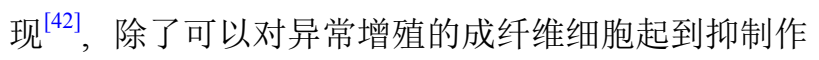
用外, 还可以调控正常成纤维细胞的胶原合成功能 ${ }^{[43]}$. 现阶段, 有研究提出干细胞的作用, 认为正常皮肤的干 细胞在慢性炎症的刺激下转化为痒痕疮痁干细胞, 而 放疗可能通过抑制该转化过程来达到治疗的效果 ${ }^{[44]}$. 放疗的临床效果显著, 但是面部、腺体部位则属于放 疗的相对禁忌, 以免发生面部容貌改变、视力减退、 腺体功能障碍等. 放疗目前已然是一种较成熟的㓔痕 疮㾑治疗手段, 但是由于其急性和慢性不良反应的存 在, 临床主要通过改善放疗的剂量和时间来进一步减 少不良反应的出现.

近5年, 临床的主要研究热点在于保守治疗或㓔痕 疮㾑切除术后的辅助治疗方面.

药物治疗是首选的㓔痕疮㾂保守治疗手段, 也可 应用于痒痕疮㾂切除术后. 目前的临床一线用药是皮 质类固醇药物和抗肿瘤药物. 皮质类固醇药物包括曲 安奈德、得宝松等, 主要的作用机制是抑制成纤维细 胞的增殖水平、降低细胞外基质的含量 ${ }^{[45]}$; 抗肿瘤药
物包括5-氟尿嘧啶、博来需素、秋水仙碱等, 主要的 作用机制是阻止细胞的有丝分裂 ${ }^{[46]}$. 除了上述药物外, 硅酮凝胶类、干扰素、他克莫司等也是较为常用的疫 痕疮痁治疗药物. 近些年来较为新颖的药物包括植物 提取物 ${ }^{[47]}$ 、胶原酶 ${ }^{[48]}$ 等. 以上较为新颖的药物, 在部 分临床研究中较为有效, 但也有研究指出相关的不良 反应，可能会限制其广泛的临床应用 ${ }^{[49]}$. 根据医师的 个人经验和用药习惯，本文总结了目前临床常用的痒 痕疮㽽治疗药物并对比了其作用机制、不良反应和应 用局限性(表1).

瘏痕疮㾑其他方面的辅助治疗包括激光治疗、放 射治疗、冷冻治疗、加压治疗等. 近些年来, 以上治疗 方式的机制和临床效果已经得到证实, 虽然属于痒痕 疮㾂的辅助治疗手段, 也多根据患者的具体情况和医 师的个人经验进行选择, 但是除放射治疗外, 其余的 辅助治疗手段应用较为局限 ${ }^{[28]}$.

综上所述, 㓔痕疮瘩的临床治疗仍然以手术治疗 为主, 保守治疗为辅. 目前痈痕疮㾂的临床一线用药 已应用近 30 余年，虽然有较高概率(超过 $30 \%$ )发生皮 肤萎缩、毛细血管扩张、色素沉着、皮肤溃疡等不良 反应 ${ }^{[0 \sim 52]}$, 但目前仍无比较令人满意的临床替代药物 出现, 而对于新型药物的研发也处于较为早期的阶段. 新研发的药物拟在具有疗效的同时, 尽可能地减少药 物用量和不良反应.

\section{3 㓔痕疮㽽治疗方面临床转化的进展及 分析}

瘏痕疮㾑的临床转化, 归根到底是要应用于㓔痕 疮㽽的临床治疗, 服务于瘷痕疮㾂患者, 在此本团队 搜索相关文献, 总结了以下 3 项具有临床转化意义的 㓔痕疮㾑治疗进展.

\section{1 新型化疗药物2-甲氧基雌二醇}

新型化疗药物2-甲氧基雌二醇 (2-methoxyestradiol, 2ME2)是雌激素的生理性代谢产物, 雌激素样活 性极弱. 目前已经有研究表明, 2ME2具有良好的抗肿 瘤效应, 其主要的作用机制在于抗血管生成, 抑制肿瘤 细胞增殖, 促进肿瘤细胞调亡和增强肿瘤细胞的放疗 敏感性 ${ }^{[53 ~ 56]}$. 2ME2于 2016 年由北京协和医院首次应 用于痏痕疮痁的治疗效应研究, 该药物可以促进痏痕 
表 1 临床常用药物对比及主要局限性

Table 1 Comparison of commonly used clinical drugs and main limitations

\begin{tabular}{|c|c|c|c|c|}
\hline 药物分类 & 药物名称 & 作用机制 & 不良反应 & 主要局限性 \\
\hline 激素类药物 & 曲安奈德 & $\begin{array}{c}\text { 增加胶原降解, 减少胶原合成和成 } \\
\text { 纤维细胞的增殖 }\end{array}$ & $\begin{array}{l}\text { 局部疼痛、毛细血管扩张、 } \\
\text { 色素沉着或缺失、组织萎缩等 }\end{array}$ & $\begin{array}{c}\text { 局部疼痛、毛细血管扩张 } \\
\text { 引起红斑 }\end{array}$ \\
\hline \multirow[t]{2}{*}{ 抗肿瘤药物 } & 5-氟尿嘧啶 & $\begin{array}{c}\text { 抑制DNA和RNA的合成, 减少腺苷酸合 } \\
\text { 酶活动 }\end{array}$ & $\begin{array}{c}\text { 局部剧烈疼痛, 皮肤溃疡、 } \\
\text { 皮肤坏死等 }\end{array}$ & 疼痛剧烈 \\
\hline & 博来霵素 & $\begin{array}{c}\text { 产生活性氧抑制DNA、RNA及蛋白质合 } \\
\text { 成, 阻断细胞周期循环 }\end{array}$ & $\begin{array}{c}\text { 色素沉着、雷诺现象、脱发、 } \\
\text { 水中、脏器纤维化等 }\end{array}$ & 色素沉着显著, 消退困难 \\
\hline 免疫类药物 & 干扰素 & 抑制成纤维细胞增殖, 促进胶原降解 & $\begin{array}{c}\text { 局部水肿、局部疼痛、流感样 } \\
\text { 综合征等 }\end{array}$ & 价格昂贵 \\
\hline 生物制剂 & A型肉毒毒素 & $\begin{array}{c}\text { 抑制神经末梢释放乙酰胆碱, } \\
\text { 使肌肉松弛、局部皮肤张力减少 }\end{array}$ & 不良反应少见 & 大面积治疗价格昂贵 \\
\hline 外用凝胶 & 硅酮凝胶 & 减少皮肤水分流失, 软化痏痕 & 皮肤过敏 & 治疗周期较长 \\
\hline 植物提取物 & 积雪苷片 & 促进愈合, 抑制成纤维细胞增殖 & 不良反应少见 & 治疗周期较长 \\
\hline
\end{tabular}

疮痁成纤维细胞的调亡水平, 并增加其放疗敏感性, 且 药物用量和药物毒性较低 ${ }^{[57 ~ 60]}$. 2019年，熊瑛等人 ${ }^{[61]}$ 将2ME2应用于临床，研究中将点阵激光联合2ME2治 疗瘕痕疮㽽，除了具有满意的治疗效果以外，其不良 反应的发生率较对照组也显著降低, 自此打开了 2ME2基础研究向临床应用转化的道路. 虽然目前关 于该药物的研究较少，但2ME2因其有效性和低毒性 仍有望成为瘏痕疮㾂治疗的新兴药物而广泛应用于临 床, 因此仍需进一步推进其基础和临床方面的研究.

\subsection{A型肉毒毒素}

A型肉毒毒素(botulinum neurotoxin type A, BoNT-A)主要用于治疗肌肉过度或不适当的收缩. BoNT-A在2002年才被美国食品和药物管理局批准应 用于矫正眉间和眼周的皱纹 ${ }^{[62]}$, 此外, BoNT-A在整形 外科其他领域的应用大多数均为适应证外使用 ${ }^{[63]}$. 在 过去的 10 年间, 有多篇临床研究指出BoNT-A治疗痒 痕疙㾂的有效性 ${ }^{[64 ~ 66]}$, 其基础作用机制研究方面也提

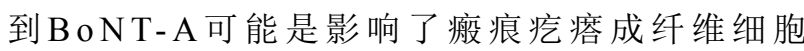
S100A4, TGF- $\beta 1$, VEGF, MMP1等因子的表达 ${ }^{[67]}$. 但 也有相应的研究并不赞同BoNT-A治疗瘷痕疮㾂的有 效性 ${ }^{[68]}$. BoNT-A在整形外科领域应用多年, 应用效果 有目共睹，但是在瘏痕疮㾂领域的应用也只是近 10 年 的事情, 虽然属于较成功的临床转化成果, 但是目前 BoNT-A的作用机制方面仍缺乏较完整和系统的基础 研究作为支持.

\section{3 高压氧治疗}

高压氧治疗(hyperbaric oxygen treatment, HBOT) 是临床常规的治疗方式, 已经应用了数十年, 在整形外科往往用于减少皮瓣的缺血再灌注损伤以 及促进愈合等方面 ${ }^{[69]}$. $\mathrm{Ma}$ 等人 ${ }^{[70]}$ 针对于痏痕疮㾂上 皮间质转化现象的研究发现, 瘢痕疮㾂组织处于之氧 状态, 其中的乏氧诱导因子 $1 \alpha$ 是重要的靶点因子. 根 据该研究结果, 高压氧也首次应用于瘕痕疮㾂的临床 治疗, 并且有研究发现, 高压氧可以改善疫痕疮㾂组 织中上皮间质转化现象 ${ }^{[71]}$ 、临床患者瘙痒疼痛症 状 ${ }^{[72]}$ 以及术后的复发率 ${ }^{[73]}$. 高压氧应用于痏痕疮㾑 的治疗是目前较为成功的临床应用转化, 虽然其基 础研究比BoNT-A更丰富, 但仍缺乏作用机制方面的 研究内容.

\section{4 㓔痕疮㽽治疗方面临床转化的“后备军”}

Zuk等人于 2001 年首次从人的脂肪组织中提取出 具有多向分化潜能的干细胞，并于2003年的第二节国 际脂肪应用技术年度会议上将其命名为ADSCs(adipose-derived stem cells). ADSCs取材容易、来源广 泛、对人体的损伤小且免疫原性低等多种优点使其广 泛应用于临床各种疾病的治疗 ${ }^{[74]}$. ADSCs对于瘕痕疮 㾂的治疗作用, 在近些年来也是研究的热点. 其主要的 机制包括干扰TGF- $\beta /$ Smad信号通路从而减少细胞外 基质的生成、降低旁分泌作用抑制成纤维细胞活性、 
降低免疫调节作用减少局部炎症因子的表达等 ${ }^{[75 ~ 78]}$. 目前尚无明确的研究证据表明ADSCs对痈痕疮㾂具 有治疗性作用，但是ADSCs在整形外科具有潜在的应 用价值，在不远的未来，可以作为痈痕疮㾂治疗方面 临床转化的“后备军”.

\section{5 总结和展望}

由于㓔痕疮㽽的发病机制尚不明确，因此瘕痕疮 㾂一直是整形外科治疗方面的难题. 目前痈痕疮㽽的 基础研究十分丰富和广泛, 但主要围绕较为经典的致 病假说开展, 其中免疫学假说中的炎症、张力假说、 干细胞假说已经成为目前的研究热点. 临床的主要研 究热点在于保守治疗或瘘痕疮㾂切除术后的辅助治疗
方面，新的临床研究尚无法撼动目前临床的一线治疗 方案, 但基础研究的参与, 为临床治疗的有效性提供 了理论方面的解释.

综上所述, 对于基础研究来说, 临床转化力量还有 所欠缺, 虽然有较成功的临床转化案例, 但是离大面积 临床应用还存在一定的距离. 未来瘷痕疮㾂的基础研 究方面任重而道远，本文认为可以分为三个方面：第 一, 仍需进一步加强对于痏痕疮㾂发病机制以及病理 生理学的研究; 第二, 对于部分临床证实有效的治疗 手段, 其作用机制尚缺乏基础医学方面的支撑; 第三, 基础研究仍应考虑到临床转化应用的前景. 在临床研 究方面, 可考虑推进整形外科专科药物的研发, 在保 证疗效的同时，为患者减少创伤和药物所带来的不良 反应。

\section{参考文献}

1 Satish L, Lyons-Weiler J, Hebda P A, et al. Gene expression patterns in isolated keloid fibroblasts. Wound Repair Regen, 2006, 14: 463-470

2 Trace A P, Enos C W, Mantel A, et al. Keloids and hypertrophic scars: a spectrum of clinical challenges. Am J Clin Dermatol, 2016, 17: 201-223

3 Kassi K, Kouame K, Kouassi A, et al. Quality of life in black African patients with keloid scars. Dermatol Rep, 2020, 12: 8312-8315

4 Osti E. Skin $\mathrm{pH}$ variations from the acute phase to re-epithelialization in burn patients treated with new materials (Burnshield ${ }^{\mathbb{B}}$, semipermeable adhesive film, Dermasilk $^{\circledR}$, and Hyalomatrix ${ }^{\circledR}$ ). Non-invasive preliminary experimental clinical trial. Ann Burns Fire Disasters, 2008, 21: 73-77

5 Majumder A, Srivastava S, Ranjan P. Squamous cell carcinoma arising in a keloid scar. Med J Armed Forces India, 2019, 75: 222-224

6 Zhang M Y, Ding G F, He Q, et al. Bibliometric and visual analysis of current status and trends of international research on keloids (in Chinese). Chin J Burn, 2021, 37: 1-12 [张梦圆, 丁高峰, 贺琼, 等. 疫痕疮㽽国际研究现状及趋势的文献计量和可视化分析. 中华烧伤杂志, 2021, 37: $1-12]$

7 Janssen de Limpens A M P, Cormane R H. Studies on the immunologic aspects of keloids and hypertrophic scars. Arch Dermatol Res, 1982, 274: $259-266$

8 Murao N, Seino K I, Hayashi T, et al. Treg-enriched $\mathrm{CD}^{+}$T cells attenuate collagen synthesis in keloid fibroblasts. Exp Dermatol, 2014, 23: 266-271

9 Chen Z, Zhou L, Won T, et al. Characterization of CD45RO ${ }^{+}$memory T lymphocytes in keloid disease. Br J Dermatol, 2018, 178: 940-950

10 Lee S, Kim S K, Park H, et al. Contribution of autophagy-notch1-mediated NLRP3 inflammasome activation to chronic inflammation and fibrosis in keloid fibroblasts. Int J Mol Sci, 2020, 21: 8050-8064

11 Ud-Din S, Wilgus T A, Bayat A. Mast cells in skin scarring: a review of animal and human research. Front Immunol, 2020, 11: 552205

12 Limandjaja G C, Niessen F B, Scheper R J, et al. The keloid disorder: heterogeneity, histopathology, mechanisms and models. Front Cell Dev Biol, 2020, 8: 360-386

13 Harn H I C, Ogawa R, Hsu C K, et al. The tension biology of wound healing. Exp Dermatol, 2019, 28: 464-471

14 Rippa A L, Kalabusheva E P, Vorotelyak E A. Regeneration of dermis: scarring and cells involved. Cells, 2019, 8: 607-637

15 Song H F, Dong G H, Wei K J, et al. Tension promotes keloid fibrosis: a preliminary study (in Chinese). Chin J Dermatol, 2021, 54: 196-200 [宋 海峰, 董高宏, 魏凯军, 等. 张力促进痈痕疮㾑纤维化的初步研究. 中华皮肤科杂志, 2021, 54: 196-200]

16 Arima J, Dohi T, Kuribayashi S, et al. Z-plasty and postoperative radiotherapy for anterior chest wall keloids. Plast Reconstr Surg Glob Open, 2019, 7: e2177

17 Tsuge T, Aoki M, Akaishi S, et al. Geometric modeling and a retrospective cohort study on the usefulness of fascial tensile reductions in severe keloid surgery. Surgery, 2020, 167: 504-509 
18 Wang Y, Ma J, Zhang Z, et al. Combined surgical excision and electron external beam radiation improves the treatment of keloids: a descriptive study. Dermatol Ther, 2020, 33

19 Mankowski P, Kanevsky J, Tomlinson J, et al. Optimizing radiotherapy for keloids: a meta-analysis systematic review comparing recurrence rates between different radiation modalities. Ann Plast Surg, 2017, 78: 403-411

20 Ford L C, King D F, Lagasse L D, et al. Increased androgen binding in keloids: a preliminary communication. J Dermatol Surg Oncol, 1983, 9: $545-547$

21 Yeung H, Kahn B, Ly B C, et al. Dermatologic conditions in transgender populations. Endocrinol Metab Clin North Am, 2019, 48: 429-440

22 Schierle H P, Scholz D, Lemperle G. Elevated levels of testosterone receptors in keloid tissue: an experimental investigation. Plast Reconstr Surg, 1997, 100: 390-395

23 Moustafa M F, Abdel-Fattah M A, Abdel-Fattah D C. Presumptive evidence of the effect of pregnancy estrogens on keloid growth. Plast Reconstr Surg, 1975, 56: 450-453

24 Mancini R E, Quaife J V. Histogenesis of experimentally produced keloids. J Invest Dermatol, 1962, 38: 143-181

25 Omo-Dare P. Genetic studies on keloid. J Natl Med Assoc, 1975, 67: 428-432

26 Clark J A, Turner M L, Howard L, et al. Description of familial keloids in five pedigrees: evidence for autosomal dominant inheritance and phenotypic heterogeneity. BMC Dermatol, 2009, 9: 8-16

27 Marneros A G, Norris J E C, Watanabe S, et al. Genome scans provide evidence for keloid susceptibility loci on chromosomes 2q23 and 7p11. J Invest Dermatol, 2004, 122: 1126-1132

28 Glass II D A. Current understanding of the genetic causes of keloid formation. J Invest Dermatol Symp Proc, 2017, 18: S50-S53

29 He Y, Deng Z, Alghamdi M, et al. From genetics to epigenetics: new insights into keloid scarring. Cell Prolif, 2017, 50: e12326

30 Piletič K, Kunej T. MicroRNA epigenetic signatures in human disease. Arch Toxicol, 2016, 90: 2405-2419

31 Jones L R, Greene J, Chen K M, et al. Biological significance of genome-wide DNA methylation profiles in keloids. Laryngoscope, 2017, 127: $70-78$

32 Tsai C H, Ogawa R. Keloid research: current status and future directions. Scars Burns Heal, 2019, 5: 205951311986865

33 Hochman B, Isoldi F C, Furtado F, et al. New approach to the understanding of keloid: psychoneuroimmune-endocrine aspects. Clin Cosmet Investig Dermatol, 2015, 8: 67-73

34 Moon J H, Kwak S S, Park G, et al. Isolation and characterization of multipotent human keloid-derived mesenchymal-like stem cells. Stem Cells Dev, 2008, 17: 713-724

35 Deng C, Wang B, Zhang Z, et al. The expressions of notch genes in human keloid-derived mesenchymal-like stem cells. Chin J Plast Surg, 2014, 30: $197-202$

36 Zhang Q, Yamaza T, Kelly A P, et al. Tumor-like stem cells derived from human keloid are governed by the inflammatory niche driven by IL-17/ IL-6 axis. PLoS ONE, 2009, 4: e7798

37 Liu Q, Wang X, Jia Y, et al. Increased blood flow in keloids and adjacent skin revealed by laser speckle contrast imaging. Lasers Surg Med, 2016, 48: $360-364$

38 Wang W B, Wu X L, Gao Z. Research progress in keloid (in Chinese). J Tissue Eng Reconstr Surg, 2018, 14: 357-360 [王文波, 武晓莉, 高振. 瘏 痕疮㾂最新研究进展. 组织工程与重建外科杂志, 2018, 14: 357-360]

39 Li W, Wang Y, Wang X, et al. A keloid edge precut, preradiotherapy method in large keloid skin graft treatment. Dermatol Surg, 2014, 40: 52-57

40 Zeng A, Song K, Zhang M, et al. The "sandwich therapy": A microsurgical integrated approach for presternal keloid treatment. Ann Plast Surg, 2017, 79: 280-285

41 Grabowski G, Pacana M J, Chen E. Keloid and hypertrophic scar formation, prevention, and management. J Am Acad Orthop Surg, 2020, 28: e408-e414

42 Hsueh W T, Hung K S, Chen Y C, et al. Adjuvant radiotherapy after keloid excision. Ann Plast Surg, 2019, 82: S39-S44

43 Maemoto H, Iraha S, Arashiro K, et al. Risk factors of recurrence after postoperative electron beam radiation therapy for keloid: comparison of long-term local control rate. Rep Pract Oncol Radiother, 2020, 25: 606-611

44 Maemoto H, Ishigami K, Iraha S, et al. Analyses of size and computed tomography densitometry parameters for prediction of keloid recurrence after postoperative electron beam radiation therapy. Skin Res Technol, 2020, 26: 125-131

45 Aggarwal A, Ravikumar B C, Vinay K N, et al. A comparative study of various modalities in the treatment of keloids. Int J Dermatol, 2018, 57: 
$1192-1200$

46 Park J, Kim Y C. Topical delivery of 5-fluorouracil-loaded carboxymethyl chitosan nanoparticles using microneedles for keloid treatment. Drug Deliv Transl Res, 2021, 11: 205-213

47 Expert Group of Scar Medicine, Plastic and Cosmetic Association of China. Recommended guidelines for clinical treatment of keloid in China (in Chinese). Chin J Aesthet Plast Surg, 2018, 29: 1-12 [中国整形美容协会痈痕医学分会常委会专家组. 中国瘏痕疮㽽临床治疗推荐指南. 中国 美容整形外科杂志, 2018, 29: 1-12]

48 Bae-Harboe Y S C, Harboe-Schmidt J E, Graber E, et al. Collagenase followed by compression for the treatment of earlobe keloids. Dermatol Surgy, 2014, 40: 519-524

49 Kang N, Sivakumar B, Sanders R, et al. Intra-lesional injections of collagenase are ineffective in the treatment of keloid and hypertrophic scars. J Plast Reconstr Aesthet Surg, 2006, 59: 693-699

50 Guler Y, Erbin A, Ozmerdiven G. Keloid formation after circumcision: a case report and current literature review. Folia Med, 2020, 62: 601-604

51 Srivastava S, Patil A, Prakash C, et al. Comparison of intralesional triamcinolone acetonide, 5-fluorouracil, and their combination in treatment of keloids. World J Plast Surg, 2018, 7: 212-219

52 Chua S C, Gidaszewski B, Khajehei M. Efficacy of surgical excision and sub-dermal injection of triamcinolone acetonide for treatment of keloid scars after caesarean section: a single blind randomised controlled trial protocol. Trials, 2019, 20: 363-372

53 Kouvaras E, Christoni Z, Siasios I, et al. Hypoxia-inducible factor 1-alpha and vascular endothelial growth factor in cartilage tumors. Biotech Histochem, 2019, 94: 283-289

54 Gorska-Ponikowska M, Kuban-Jankowska A, Daca A, et al. 2-Methoxyestradiol reverses the pro-carcinogenic effect of L-lactate in Osteosarcoma 143B cells. Cancer Genomics Proteomics, 2017, 14: 483-493

55 Nolte E M, Joubert A M, Lakier R, et al. Exposure of breast and lung cancer cells to a novel estrone analog prior to radiation enhances Bcl-2mediated cell death. Int J Mol Sci, 2018, 19: 2887

56 Neamatallah T, Abdel-Naim A B, Eid B G, et al. 2-Methoxyestradiol attenuates liver fibrosis in mice: implications for M2 macrophages. Naunyn Schmiedebergs Arch Pharmacol, 2019, 392: 381-391

57 Long F, Si L, Long X, et al. 2ME2 increase radiation-induced apoptosis of keloid fibroblasts by targeting HIF-1 $\alpha$ in vitro. Australas J Dermatol, 2016, 57: e32-e38

58 Zhang M Z, Liu Y F, Ding N, et al. 2-Methoxyestradiol improves the apoptosis level in keloid fibroblasts through caspase-dependent mechanisms in vitro. Am J Transl Res, 2018, 10: 4017-4029

59 Si L B, Huang J N, Zhang M Z, et al. The effect of 2-methoxyestradiol on the expression of Bcl-2, Bax and cell activity of keloid fibroblasts (in Chinese). Oncol Progr, 2017, 15: 1409-1411 [斯楼斌, 黄健楠, 张明子, 等. 2-甲氧基雌二醇对瘷痕疮㾂成纤维细胞活性及Bcl-2和Bax表达水 平的影响. 癌症进展, 2017, 15: 1409-1411]

60 Zhang M Z, Huang J N, Liu Y F, et al. The effect of 2-methoxyestradiol on the expression of caspase-3, caspase-8 and cytochrome-C in keloid fibroblasts (in Chinese). Chin J Aesthet Plast Surg, 2018, 29: 595-598 [张明子, 黄健楠, 刘艺芳, 等. 2-甲氧基雌二醇对瘏痕疠㾂成纤维细胞 caspase-3、caspase-8及细胞色素C表达水平的影响. 中国美容整形外科杂志, 2018, 29: 595-598]

61 Xiong Y, Chai B, Chen T, et al. Effect on VSS and TGF- $\beta 1$ in patients with keloid using lattice laser combined with 2-methoxyestradiol (in Chinese). Chin J Aesthet Med, 2019, 28: 49-52 [熊瑛, 柴宝, 陈婷, 等. 点阵激光联合2-甲氧基雌二醇对痒痕疮㽽患者㓔痕VSS评分及TGF$\beta 1$ 的影响. 中国美容医学, 2019, 28: 49-52]

62 Erickson B P, Lee W W, Cohen J, et al. The role of neurotoxins in the periorbital and midfacial areas. Facial Plast Surg Clin North Am, 2015, 23: $243-255$

63 Dutta S R, Passi D, Singh M, et al. Botulinum toxin the poison that heals: a brief review. Natl J Maxillofac Surg, 2016, 7: 10-16

64 Pruksapong C, Yingtaweesittikul S, Burusapat C. Efficacy of botulinum toxin A in preventing recurrence keloids: double blinded randomized controlled trial study: intraindividual subject. J Med Assoc Thai, 2017, 100: 280-286

65 Bi M, Sun P, Li D, et al. Intralesional injection of botulinum toxin type A compared with intralesional injection of corticosteroid for the treatment of hypertrophic scar and keloid: a systematic review and meta-analysis. Med Sci Monit, 2019, 25: 2950-2958

66 Gamil H D, Khattab F M, El Fawal M M, et al. Comparison of intralesional triamcinolone acetonide, botulinum toxin type A, and their combination for the treatment of keloid lesions. J Dermatol Treat, 2020, 31: 535-544

67 Xiaoxue W, Xi C, Zhibo X. Effects of botulinum toxin type A on expression of genes in keloid fibroblasts. Aesthet Surg J, 2014, 34: 154-159 
Haubner F, Leyh M, Ohmann E, et al. Effects of botulinum toxin A on patient-specific keloid fibroblasts in vitro. Laryngoscope, 2014, 124: $1344-1351$

69

Bassetto F, Bosco G, Brambullo T, et al. Hyperbaric oxygen therapy in plastic surgery practice: case series and literature overview. J Surg, 2019, 40: $257-275$

70 Ma X, Chen J, Xu B, et al. Keloid-derived keratinocytes acquire a fibroblast-like appearance and an enhanced invasive capacity in a hypoxic microenvironment in vitro. Int J Mol Med, 2015, 35: 1246-1256

71 Zhang M, Liu S, Guan E, et al. Hyperbaric oxygen therapy can ameliorate the EMT phenomenon in keloid tissue. Medicine, 2018, 97: e11529

72 Li W B, Liu S, Zhang M Z, et al. Hyperbaric oxygen therapy relieved pruritus and pain of keloid patients. Am J Transl Res, 2020, 12: 574-582

73 Song K X, Liu S, Zhang M Z, et al. Hyperbaric oxygen therapy improves the effect of keloid surgery and radiotherapy by reducing the recurrence rate. J Zhejiang Univ Sci B, 2018, 19: 853-862

Chiang R S, Borovikova A A, King K, et al. Current concepts related to hypertrophic scarring in burn injuries. Wound Rep Reg, 2016, 24: 466477

76 Park J, Lee J H, Yoon B S, et al. Additive effect of bFGF and selenium on expansion and paracrine action of human amniotic fluid-derived mesenchymal stem cells. Stem Cell Res Ther, 2018, 9: 293

77 Xie F, Teng L, Xu J, et al. Adipose-derived mesenchymal stem cells inhibit cell proliferation and migration and suppress extracellular matrix synthesis in hypertrophic-scar and keloid fibroblasts. Exp Ther Med, 2021, 21: 139

78 Jiao Y, Wang X, Zhang J, et al. Inhibiting function of human fetal dermal mesenchymal stem cells on bioactivities of keloid fibroblasts. Stem Cell Res Ther, 2017, 8: 170

\title{
Progress and analysis of basic and clinical research and clinical transformation of keloids
}

\author{
ZHANG MingZi, ZHANG WenChao, LONG Fei, SI LouBin, YU NanZe, ZENG Ang, LIU ZhiFei, \\ SONG KeXin, WANG YouBin, LONG Xiao \& WANG XiaoJun \\ Department of Plastic Surgery, Peking Union Medical College Hospital, Chinese Academy of Medical Sciences \& Peking Union Medical College, \\ Beijing 100730, China
}

Keloid, regarded as a benign tumor of the skin, has been challenging in terms of treatment in the field of plastic surgery because of its unclear pathogenesis. In recent years, basic and clinical studies on keloid have been quite abundant, and there have also been successful cases of clinical transformation. In this review, we have summarized and analyzed keloid-related research conducted in the past 20 years, discussed the progress of basic and clinical studies as well as those on the clinical transformation of keloid, and speculated about its future research direction.

keloid, basic research, clinical research, clinical transformation, progress

doi: $10.1360 /$ SSV-2021-0104 